\title{
HUBUNGAN ANTARA GAYA HIDUP DAN PEMILIHAN MEREK LOKAL ATAU MEREK LUAR NEGERI (SURVEI PADA AYAM BAKAR WONG SOLO VS KENTUCKY FRIED CHICKEN)
}

\author{
Budhi Haryanto \\ Fakukltas Ekonomi Universitas Sebelas Maret Surakarta \\ e-mail: budhiharyanto@yahoo.com \\ Awang Febrianto \\ Fakultas Ekonomi Universitas Sebelas Maret Surakarta \\ e-mail: awang.febrianto@gmail.com
}

\begin{abstract}
This study examines the influence of lifesyle on probability in buying intention toward domestic brand (Ayam Bakar Wong Solo) or foreign brand (Kentucky Fried Chicken). Convenience sampling method was employed to acquire 250 samples with the criteria of: (1) the respondents had the intention to buy Ayam Bakar Wong Solo or has intention to buy Kentucky Fried Chicken, (2) respondents had the freedom to take or to refuse to paticipate in the survey. (3) Survey was conducted in the form of direct structured intervew. These conditions were intended to get data acuracy. Logit regression was utilized to predict the influence of independent variable on dependent variables. The analysis indicated that consumer who had fashion conscious life style preferred to buy foreign brand (Kentucky Fried Chicken), the health conscious life style preferred on local brand (Ayam Bakar Wong Solo), leadership life style preferred on foreign brand, caring life style preferred on local brand, and extrovertion life style preferred on foreign brand. In this study, implications of the results were also discussed.
\end{abstract}

Key words: life style, local brand, foreign brand, caring life style, leadership life style, extrovertion life style.

\begin{abstract}
Abstrak
Penelitian ini bertujuan untuk menguji pengaruh gaya hidup pada kemungkinannya dalam membeli merek domestic (ayam Bakar Wong Solo) atau merek luar negeri (Kentucky Fried Chicken). Metode sampling konveniens dipilih untuk mengambil 250 responden, yang diikuti dengan kriteria (1) responden berniat membeli Ayam Bakar Wong Solo dan KFC, (2) responden mempunyai kebebasan untuk menerima atau menolak sebagai responden, (3) survei dilakukan melalui wawancara langsung secara terstruktur. Hal ini dilakukan untuk mendapatkan keakurasian data penelitian. Regresi Logistik dilakukan untuk memprediksi hubungan antar dua variabel seperti yang dihipotresiskan. Hasilnya mengindikasi bahwa konsumen yang mempunyai gaya hidup pemerhati mode cenderung membeli merek asing (KFC), sedangkan yang sadar kesehatan cenderung memilih merek lokal (Ayam Bakar Wong Solo), selanjutnya konsumen yang bergaya hidup kepemimpinan cenderung memilih merek lokal (Ayam Bakar Wong Solo), dan konsumen yang mementingkan hal-hal lahiriyah cenderung memilih merek asing (KFC). Dalam penelitian ini juga membahas implikasi dari hasil-hasil penelitian.
\end{abstract}

Kata kunci: gaya hidup, merek lokal, merek asing, gaya hidup pemerhati, gaya hidup sadar kesehatan, gaya hidup kepemimpinan, gaya hidup yang mementingkan hal-hal lahiriyah.

\section{PENDAHULUAN}

Gaya hidup atau lifestyle merupakan isu yang masih menarik untuk dikaji ulang karena belum adanya pendapat yang konklusif terhadap model yang digunakan untuk menjelaskan fenomenanya (lihat Versantvoort and Van der Laan, 1997; Kaynak and Kara, 2001; Naylor and Kleiser, 2002; Kavak and Gumusluoglu, 
2006; Atchariyachanvanich and Okada, 2007). Hal ini memberikan peluang kepada studi ini untuk mengkonstruksi model yang dapat menjelaskan fenomena gaya hidup dalam konteks proses keperilakuan konsumen yang terjadi di Indonesia.

Secara spesifik studi ini bertujuan untuk meneliti perbedaan gaya hidup dalam proses niat pembelian pada Kentucky Fried Chicken (KFC) sebagai merek asing dan Ayam Bakar Wong Solo sebagai merek lokal. Pemilihan objek penelitian diharapkan dapat menjelaskan fenomena gaya hidup dan pengaruhnya pada pemilihan produk asing dan produk lokal. Melalui studi ini diharapkan dapat menjelaskan variabel-variabel gaya hidup yang dapat digunakan untuk memprediksi niat pembelian terhadap kedua merek tersebut.

Berdasarkan hasil kajian literatur, ada 13 dimensi gaya hidup yang diperkirakan mempengaruhi pemilihan merek lokal dan asing yaitu: family orientation, fashion consciousness, health consciousness, leadership, casualness, practicality, craftsmanship, community consciousness, cost consciousness, extroversion, adventurism, interest in sport, caring (Lihat Kavak and Gumusluoglu, 2006).

\section{TINJAUAN PUSTAKA}

Gaya hidup didefinisi sebagai orientasi individual yang menciptakan struktur hidup seseorang, selain itu gaya hidup juga mendeskripsikan nilai-nilai yang melekat pada setiap individu yang berbeda (lihat Versantvoort and Van der Laan, 1997). Konsep ini berawal dari penelitian yang dilakukan oleh Well and Tigert (1977) yang meneliti kaitan dimensi gaya hidup sebagai dasar untuk melakukan segmentasi pasar. Dalam studinya, gaya hidup dari individu yang dideskripsikan merupakan hasil reduksi dari 3 faktor yang menjelaskan activities, interests, dan opinions (AIO). Selanjutnya konsep ini (AIO) dikembangkan oleh Assael (1998) untuk menjelaskan karakteristik psikografis individu sebagai orientasi psikologi yang dapat diukur.

Studi yang berbeda dilakukan oleh Micthcell (1981) yang memperkenalkan konsep dengan skala values dan lifestyle (VALS), konsep ini dianggap superior karena merupakan hasil integrasi dari AIO dan values. Selanjutnya pendekatan ini dikembangkan untuk mengukur sikap, kepercayaan, opini, harapan, rasa takut, bias, kebutuhan, dan expetasi dari konsumen, yang berhubungan dengan konsep psikologi konsumen (lihat Shieh et al., 2007).

Studi ini bertujuan memberikan pemahaman terkait dengan dimensi-dimensi gaya hidup seperti: family orientation, fashion consciousness, health consciousness, leadership, casualness, practicality, craftsmanship, community consciousness, cost consciousness, extroversion, adventurism, interest in sport, caring sebagai dasar segmentasi dan menjelaskan pengaruh dari masing-masing dimensi tersebut pada niat pembelian suatu produk. Hal ini dimaksudkan untuk memberikan pertimbangan kepada pemasar terkait dengan perumusan strategi-strateginya untuk meningkatkan niat pembelian kosumen. Posisi studi ini dibandingkan dangan studi-studi yang sebelumnya dapat dijelaskan melalui variabel variabel yang digunakan untuk mengkonstruksi model dan alat analisis yang digunakan untuk pengujian (Lihat Tabel 1).

Dalam studi ini, ada 13 gaya hidup yang digunakan untuk menjelaskan nat pembelian merek local atau asing. Family orientation merupakan salah satu gaya hidup yang secara spesifik dapat dilihat melalui jumlah anak yang dimiliki dalam sebuah keluarga, status pernikahan (single atau berkeluarga), tinggal bersama orangtua atau sendiri, dan frekuensi melakukan kontak dengan anggota keluarga (Lihat Versantvoort and Van der Laan, 1997). Selanjutnya, fashion consciousness merupakan gaya hidup dengan karakteristik yang berkecenderungan untuk menyt kai produk baru dan inovatif, memperoleh kesenangan dari mencari hal-hal yang baru, serta sadar pada fashion dan mode terbaru. Individu seperti ini kurang berhati-hati dalam berbelanja, lebih impulsif, dan kurang peka terhadap harga (Lihat Sproles and Kendall, 1990).

Health consciousness merupakan gaya hidup berikutnya yang menjelaskan karakteristik individu yang memiliki suatu kesadaran tentang pentingnya kesehatan. Individu dengan karakteristik seperti ini biasanya sangat selektif sekali dalam melakukan pemilihan sebuah produk yang dikonsumsi untuk kesehatannya (Lihat Kavak and Gumusluoglu, 2006). Selanjutnya, leadership menjelaskan karakteristik individu yang memiliki jiwa kepemimpinan 
dengan ciri-ciri sebagai berikut: mempunyai kepercayaan diri yang tinggi, memiliki kemampuan sebagai pemimpin, mempunyai keinginan yang kuat untuk menjadi pemimpin, dapat mempengaruhi orang lain (Lihat Kavak and Gumusluoglu, 2006). Sedangkan casualness menjelaskan suatu karateristik dari individu yang menyukai sesuatu yang tidak formal. Individu yang memiliki gaya hidup seperti ini biasanya kurang begitu memperhatikan kebersihan, penampilan ataupun kegiatan lain yang dianggap formal (lihat Kavak and Gumusluoglu, 2006).

Literatur juga menjelaskan bahwa practicality merupakan karakteristik individu yang diartikan sebagai sifat individu yang menyukai hal-hal praktis. Ciri-ciri dari individu dengan gaya hidup seperti ini adalah sebagai berikut: menyukai produk-produk yang simple dan praktis contohnya adalah produk makanan kaleng, beranggapan bahwa memiliki kartu kredit adalah hal yang praktis karena (Lihat Kavak and Gumusluoglu, 2006). Sedangkan craftsmanship menjelaskan karakteristik seseorang yang mempunyai keterampilan ataupun keahlian lebih daripada orang lain. Biasanya konsumen seperti ini memanfaatkan keterampilannya itu dengan menciptakan suatu barang/ produk untuk dikonsumsi sendiri ataupun diperdagangkan (Lihat Kavak and Gumusluoglu, 2006). Berikutnya adalah cost consciousness yang menjelaskan suatu karakteristik individu yang mempunyai kesadaran tinggi terhadap harga. Individu dengan gaya hidup seperti ini selalu mencari nilai terbaik untuk setiap biaya yang dikeluarkan (Lihat Sproles and Kendall, 1990).

Tabel 1: Posisi studi

\begin{tabular}{|c|c|c|c|c|c|}
\hline Penulis/Tahun Penelitian & Variabel Independent & $\begin{array}{l}\text { Variabel } \\
\text { mediasi }\end{array}$ & Variabel Dependen t & $\begin{array}{l}\text { Variabel } \\
\text { Moderator }\end{array}$ & Metode statistik \\
\hline Kaynak \& Kara (2001) & $\begin{array}{l}\text { - country of origin } \\
\text { - } \text { product class knowledge } \\
\text { - consumer characteristics } \\
\text { - country characteristics }\end{array}$ & & $\begin{array}{l}\text { - product brand } \\
\text { perceptions } \\
\text { - perceptions of price } \\
\text { - purchase intentions } \\
\text { - choise of brand } \\
\text { - purchase of brand }\end{array}$ & $\begin{array}{l}\text { consumer } \\
\text { ethnocentrism }\end{array}$ & ANOVA \\
\hline $\begin{array}{l}\text { Kavak \& Gumusluoglu } \\
(2006)\end{array}$ & $\begin{array}{l}\text { - lifestyle } \\
\text { - ethnocentrism }\end{array}$ & & purchasing intentions & & $\begin{array}{l}\text { Logistic } \\
\text { regression } \\
\text { analysis } \\
\end{array}$ \\
\hline Shieh \& Cheng (2007) & $\begin{array}{l}\text { - experiential value } \\
\text { - gaya hidup }\end{array}$ & & satisfaction & & SEM \\
\hline $\begin{array}{l}\text { Atchariyachanvanich } \\
\text { \& Okada (2007) }\end{array}$ & $\begin{array}{l}\text { - Net-oriented } \\
\text { Gaya hidup } \\
\text { - Innovative } \\
\text { Gaya hidup } \\
\text { - Price-oriented } \\
\text { Gaya hidup }\end{array}$ & $\begin{array}{l}\text { - Perceived } \\
\text { Risk } \\
\text { - Compatibility }\end{array}$ & $\begin{array}{l}\text { Purchasing } \\
\text { behavior }\end{array}$ & & SEM \\
\hline
\end{tabular}


Selanjutnya community consciousness dapat dijelaskan sebagai kesadaraan individu dalam kehidupan sosial dan menganggap bahwa mereka merupakan bagian dari suatu komunitas masyarakat. Karakteristik dari individu yang memiliki gaya hidup seperti ini adalah individu-individu yang aktif didalam organiasasi masyarakat maupun organisasi politik (Lihat Kaynak and Kara, 2001). Se dangkan extroversion dapat dijelaskan sebagai karakteristik individu yang lebih mementingkan hal-hal yang bersifat lahiriah seperti lebih menyukai datang kesebuah pesta dari pada berdiam diri dirumah (Lihat Kavak and Gumusluoglu, 2006). Selanjutnya adventurism dapat dijelaskan sebagai karakteristik individu yang menyukai petualangan dan menemukan hal-hal yang baru ditempat yang berbeda. Individu dengan gaya hidup seperti ini juga sangat menyukai hal-hal yang dianggap menantang bagi dirinya (Lihat Kaynak and Kara, 2001).

Berikutnya adalah interest in sport yang menjelaskan ketertarikan individu dalam bidang olahraga. Gaya hidup seperti ini memiliki karateristik: (1) mendengarkan berita atau menyaksikan pertandingan olahraga, (2) melakukan olahraga secara regular, (3) lebih memilih datang kesebuah acara olahraga daripada datang ke acara pesta (Lihat Kavak and Gumusluoglu, 2006). Terakhir adalah caring yang menjelaskan gaya hidup individu yang memperhatikan segala sesuatu yang bernilai dan dianggap penting untuk dirinya sendiri (Lihat Kavak and Gumusluoglu, 2006).

Selanjutnya dimensi gaya hidup yang terbentuk digunakan untuk menjelaskan pengaruhnya pada niat pembelian konsumen terhadap produk asing dan produk lokal. Hal ini mengacu pada penelitian Kavak and Gumusluoglu (2006) yang studinya menjelaskan 13 dimensi gaya hidup yaitu family orientation, fashion consciousness, health consciousness, leadership, casualness, practicality, craftsmanship, community consciousness, cost consciousness, extroversion, adventurism, interest in sport, caring yang mempengaruhi niat pembelian konsumen, dan hasilnya mengindikasi 4 dimensi gaya hidup (fashion conscious, health conscious, cost conscious, craftmanship) sebagai gaya hidup yang paling dominant mempengaruhi niat pembelian.

Niat Pembelian. Variabel ini didefinisi sebagai suatu niat dari konsumen untuk membeli suatu produk barang atau jasa yang disukainya (Kotler, 1994). Kaitannya dengan gaya hidup adalah dapat menjelaskan karateristik konsumen yang dapat mempengaruhi niat pembelian. Pendapat ini mengacu pada studi yang dilakukan oleh Kaynak and Kara (2001) yang menjelaskan bahwa karaketeristik psikologi konsumen mempunyai pengaruh terhadap keperilakuan kosumen yang diproxikan sengan purchasing intention, choise of brand, dan purchase of brand.

Berdasarkan argumen yang dijelaskan, maka hipotesis yang diirumuskan adalah:

$\mathrm{H}$ : tiap tiap gaya hidup konsumen mempengaruhi kecenderungannya dalam pembelian merek asing dan lokal.

\section{METODE PENELITIAN}

Target populasi dalam studi ini adalah konsumen yang berniat untuk membeli KFC sebagai merek asing dan Ayam Bakar Wong Solo sebagai merek lokal. Sampel diambil sebanyak 250 orang secara convenience dari masyarakat Surakarta, dengan ketentuan sebagai berikut: (1) berniat terhadap pembelian terhadap KFC atau Ayam Bakar Wong Solo, (2) setiap responden hanya mempunyai satu kali kesempatan untuk di survei, dan (3) responden bebas menerima atau menolak survei, dan tidak ada ikatan kekerabatan, intimidasi atau hadiah-hadiah dalam bentuk apapun yang dapat menurunkan derajat keyakinan terhadap kualitas data yang dikumpulkan. Hal ini didasarkan pada pertimbangan aspek kualitas responden dan aspek kriteria minimal kelayakan dalam penganalisisan data sesuai metode statistik yang digunakan (Hair et al., 1998).

Pengumpulan data dilakukan melalui survey pada responden dengan cara melakukan wawancara langsung yang dipandu dengan kuesioner. Hal ini dimaksudkan untuk meningkatkan keseriusan dalam pengisian kuesioner sehingga diharapkan mendapatkan data yang akurat. variabel.

Berikut ini adalah definisi operasional

Family Orientation Variabel ini di definisi sebagai individu yang berorientasi kepada keluarga. Indikan-indikan yang menjelaskan variabel ini yaitu sebagai berikut: (1) sangat mengkhawatirkan kesehatan anak, (2) anak merupakan hal yang paling utama, (3) menata 
rumah untuk kenyamanan anak, (4) memberikan contoh kebiasaan yang baik untuk anak, (5) menggunakan iklan sebagai bahan pertimbangan untuk melakukan pembelian, (6) mempunyai keinginan memiliki uang yang lebih banyak untuk tahun berikutnya, (7) dalam jangka waktu 5 tahun, keuangan keluarga akan lebih meningkat daripada tahun ini.

Fashion Consciousness. Variabel ini menjelaskan suatu gaya hidup dengan karakteristik yang menyukai produk baru dan inovatif, memperoleh kesenangan dari mencari hal-hal yang baru, serta sadar pada fashion dan mode terbaru. Indikan-indikan yang dapat menjelaskan karateristik ini yaitu seperti : (1) lebih memilih berpakaian untuk fashion daripada untuk kenyamanan, (2) selalu mencoba model rambut terbaru, (3) selalu mendatangi toko yang baru terlebih dahulu daripada orang lain, (4) menghabiskan waktu dalam membicarakan suatu produk/brand dengan temantemannya, (5) mempertimbangkan saran dari orang lain didalam memilih suatu $b r a n d$.

Health Consciousness. Variabel ini didefinisi sebagai karakteristik dari konsumen yang mempunyai kesadaran yang tinggi akan pentingnya kesehatan. Indikan-indikan yang menjelaskan gaya hidup ini adalah: (1) mengkonsumsi minuman soft drink yang rendah kalori, (2) mengkonsumsi makanan yang rendah kalori, (3) melakukan diet.

Leadership. Dimensi gaya hidup seperti ini dapat dijelaskan melalui indikanindikan seperti: (1) mempunyai kepercayaan diri yang tinggi, (2) merasa memiliki kemampuan yang lebih, (2) hidup mandiri daripada orang lain, (3) mempunyai keinginan yang kuat untuk menjadi pemimpin, (4) selalu dimintai pendapat dan saran oleh orang lain, (5) memberikan pengaruh kepada orang lain dalam membeli sesuatu.

Casualness. Indikan-indikan yang dapat menjelaskan karateristik ini yaitu seperti: (1) tidak suka membersihkan rumah/kamarnya, (2) menganggap membersihkan rumah adalah sebuah tugas yang tidak menyenangkan, (3) menyukai pembayaran secara cash dari setiap barang yang dibeli.

Practicality. Variabel ini didefinisi sebagai karakteristik konsumen yang lebih menyukai hal-hal praktis. Gaya hidup seperti ini dapat diukur dengan indikan-indikan seperti: (1) tergantung dengan produk makanan kalengan, (2) selalu berpergian dengan membawa makanan kaleng, dan (3) beranggapan bahwa memiliki kartu kredit adalah hal yang baik.

Craftsmanship. Indikan-indikan yang dapat menjelaskan karakteristik gaya hidup seperti ini adalah: (1) memiliki keinginan untuk menjadi ahli didalam keterampilan yang dimiliki, (2) sering menggunakan keterampilannya, (3) menciptakan sesuatu dari keterampilan tersebut.

Cost Consciousness. Variabel ini dapat dijelaskan melalui indikan-indikan seperti: (1) selalu melihat harga yang tertera dalam suatu produk, (2) melakukan tawar-menawar dalam melakukan pembelian, (3) dapat menghemat uang jika membuat pakaian sendiri.

Community Consciousness. Variabel ini dapat dijelaskan dengan indikan-indikan seperti: (1) anggota yang aktif didalam suatu organisasi, (2) menjadi bagian dalam kampanye politik ataupun kampanye lainya, (3) bekerja untuk kepentingan komunitas/masyarakat, (4) menjadi sukarelawan dalam kegiatan sosial.

Extroversion. Variabel ini dapat dijelaskan dengan indikan-indikan seperti: (1) meyukai pesta, (2) lebih memilih datang kesuatu pesta daripada menghabiskan waktu sendiri, dan (3) senang tinggal dirumah.

Adventurism. Variabel ini dapat dijelaskan melalui indikan-indikan sebagai berikut: (1) senang melakukan perjalanan berkeliling dunia, dan (2) menyukai menghabiskan akhir tahun di negara lain.

Interest in Sport. Variabel ini dapat dijelaskan dengan indikan-indikan sebagai berikut: (1) mendengarkan berita atau menyaksikan pertandingan olahraga, (2) melakukan olahraga secara regular, dan (3) lebih memilih datang kesebuah acara olahraga daripada datang ke acara pesta.

Caring. Variabel ini didefinisi sebagai individu yang sangat memperhatikan segala sesuatu yang bernilai dan dianggap penting untuk dirinya sendiri. Hal ini dapat dijelaskan melalui indikan-indikan seperti berikut: (1) selalu menjaga kebersihan rumah, (2) merasa tidak nyaman jika melihat rumah mereka tidak bersih.

Niat pembelian. Variabel ini diukur dengan 2 kategori yaitu 0: KFC dan 1: Ayam Bakar Wong Solo. 
Selanjutnya, data penelitian dianalisis dengan menggunakan analisis logistic regresion (logit regresion) yang merupakan bentuk khusus dari regresi yang digunakan untuk memprediksi pengaruh antara variabel independen dan dependen, dimana variabel dependennya bersifat katagorikal.

Pengukuran model estimasi koefisien ini dapat diformulasikan sebagai berikut:

$$
\begin{aligned}
& \log i t_{i}=\ln \left(\frac{\text { prob }_{\text {event }}}{1-\text { prob }_{\text {event }}}\right)=b_{0}+b_{1} X_{1}+\ldots+b_{n} X_{n} \\
& \text { Atau } \\
& o d d s_{i}=\ln \left(\frac{\text { prob }_{\text {event }}}{1-\text { prob }_{\text {event }}}\right)=e^{b_{0}+b_{1} X_{1}+\ldots+b_{n} X_{n}}
\end{aligned}
$$

Keterangan: prob $_{\text {event }}$ adalah probabilitas variabel dependen dengan variabel bebas $\mathrm{X} 1$, $\mathrm{X} 2, \ldots \ldots . . \mathrm{Xk}$. model $\log$ dari odds merupakan fungsi linear dari variabel bebas dan ekivalen dengan persamaan multiple regression dengan log dari odds sebagai variabel terikat. Variabel bebasnya dapat berupa kombinasi variabel kontinyu (metrik) maupun variabel kategorikal (non-metrik). Oleh karena log dari odds sering disebut logit maka persamaan regresinya disebut multiple logistic regression atau logistik regression (Gozali, 2004).

Pengujian model fit dari logistic regresion didasarkan pada teknik estimasi likelihood. Teknik ini merupakan probabilitas yang berkemampuan untuk memecahkan permasalahan dari model yang dihipotesiskan. Berikut ini adalah penjelasannya.

Statistik -2Log Likelihood (-2LogL). Statistik - $2 \log L$ merupakan probabilitas bahwa model yang dihipotesakan menjelaskan data input. Statistik $-2 \log L$ dapat juga digunakan untuk menentukan model fit secara signifikan jika variabel bebas (independen) ditambahkan kedalam model. Selisih $-2 \log L$ untuk model dengan konstanta saja dan $-2 \log L$ untuk model dengan konstanta dan variabel didistribusikan sebagai $x^{2}$ dengan $\mathrm{df}$ (selisih df dari kedua model).

Cox \& Snell R Square dan Nagelkerke $R$ Square. Cox dan Snell's $R^{2}$ merupakan ukuran yang mencoba meniru ukuran $\mathrm{R}^{2}$ pada multiple regression yang didasarkan pada teknik estimasi likelihood dengan nilai maksimum kurang dari 1.0 sehingga sulit diinterpretasikan. Sedangkan Nagelkerke $R$ Square merupakan modifikasi dari koefisien Cox dan Snell's untuk memastikan nilainya bervariasi dari 0.0 hingga 1.0. Hal ini dilakukan dengan cara membagi nilai Cox dan Snell's $R^{2}$ dengan nilai maksimumnya. Nilai tersebut digunakan untuk menjelaskan variabilitas variabel dependen oleh variabel independen.

Hosmer dan Lemeshow Goodness of Fit. Hosmer dan lemeshow's, model pengujian Goodness of Fit ini menguji hipotesis nol bahwa data empiris cocok atau sesuai dengan model. Jika nilai Hosmer-Lemeshow signifikan atau lebih kecil dari 0,05 maka hipotesis nol ditolak dan model dikatakan tidak fit. Sebaliknya jika tidak signifikan maka maka hipotesis nol tidak dapat ditolak yang berarti data empiris sama dengan model atau model dikatakan fit (Lihat Gozali, 2004).

\section{HASIL PENELITIAN DAN PEMBAHASAN}

Pembahasan hasil pengujian diawali dengan mereduksi indikan-indikan untuk menjelaskan segmen yang terbentuk. Dengan menggunakan Exploratory Factor Analysis (CFA), hasilnya dapat dilihat pada Tabel 2.

Berdasarkan hasil reduksian yang dilakukan, berikut ini adalah faktor-faktor yang terbentuk yang menunjukkan segmen gaya hidup individu.

Faktor 1 terdiri dari item-item yang teridentifikasi sebagai variabel fashion consciousness. Pada segmen ini, individunya bercirikan fashionable, mengikuti trend atau mode terbaru, sangat mempertimbangkan dalam melakukan pembelian terhadap suatu produk ataupun merek, menggunakan informasi dalam melakukan pembelian, dapat mempengaruhi orang lain dalam melakukan pembelian.

Faktor 2 terdiri dari item-item yang disebut dengan leadership. Karaketristik dari segmen ini adalah konsumen yang mempunyai kepercayaan diri yang tinggi, mempunyai kemampuan personal yang lebih dari pada orang lain, mempunyai keinginan menjadi seorang pemimpin.

Faktor 3 terdiri dari item-item yang disebut dengan family orientation. Karakteristik dari segmen ini adalah seperti berikut: 
mempunyai kepedulian terhadap keluarga, mengutamakan kepentingan keluarga, memberikan contoh yang baik kepada keluarga, mempunyai keinginan untuk meningkatkan financial keluarga.

Tabel 2: Hasil Reduksi

\begin{tabular}{|c|c|c|}
\hline Item-item & & Keterangan \\
\hline $\mathrm{FC} 1$ & 0,662 & Fashion Conciousness \\
\hline $\mathrm{FC} 2$ & 0,720 & \\
\hline FC3 & 0,811 & \\
\hline $\mathrm{FC} 4$ & 0,706 & \\
\hline FC5 & 0,564 & \\
\hline L1 & 0,721 & Leadership \\
\hline L2 & 0,722 & \\
\hline L3 & 0,791 & \\
\hline $\mathrm{L} 4$ & 0,691 & \\
\hline FO1 & 0,714 & FamilyOrientation \\
\hline $\mathrm{FO} 2$ & 0,697 & \\
\hline FO3 & 0,634 & \\
\hline FO4 & 0,449 & \\
\hline FO6 & 0,703 & \\
\hline FO7 & 0,573 & \\
\hline IS1 & 0,846 & Interest in Sport \\
\hline IS2 & 0,781 & \\
\hline IS3 & 0,799 & \\
\hline $\mathrm{HCl}$ & 0,719 & Health Conciousness \\
\hline $\mathrm{HC} 2$ & 0,773 & \\
\hline $\mathrm{HC} 4$ & 0,639 & \\
\hline AD1 & 0,871 & Adventurism \\
\hline $\mathrm{AD} 2$ & 0,814 & \\
\hline $\mathrm{CC} 1$ & 0,626 & Community conciousness \\
\hline $\mathrm{CC} 2$ & 0,743 & \\
\hline $\mathrm{CC} 3$ & 0,592 & \\
\hline $\mathrm{CC} 4$ & 0,490 & \\
\hline $\mathrm{C} 1$ & 0,817 & Carring \\
\hline $\mathrm{C} 2$ & 0,871 & \\
\hline $\mathrm{C} 3$ & 0,587 & \\
\hline CS1 & 0,481 & Casualness \\
\hline $\mathrm{CS} 2$ & 0,756 & \\
\hline $\mathrm{CS} 3$ & 0,699 & \\
\hline P1 & 0,762 & Practically \\
\hline P2 & 0,795 & \\
\hline P3 & 0,503 & \\
\hline CCs1 & 0,709 & Community Consiousness \\
\hline $\mathrm{CCs} 2$ & 0,722 & \\
\hline $\mathrm{CCs} 3$ & 0,712 & \\
\hline $\mathrm{CN} 1$ & 0,753 & Craftmenship \\
\hline $\mathrm{CN} 2$ & 0,811 & \\
\hline $\mathrm{CN} 3$ & 0,667 & \\
\hline EX1 & 0,667 & Extroversion \\
\hline EX2 & 0,655 & \\
\hline EX3 & 0,690 & \\
\hline
\end{tabular}

Faktor 4 terdiri dari item-item yang teridentifikasi sebagai segmen interest in sport. Karakteristik dari segmen ini adalah konsumen yang tertarik dengan olahraga dan senang menyaksikan acara olahraga, melakukan olahraga secara reguler, senang menghadiri even-even olahraga.

Faktor 5 terdiri dari item-item yang teridentifikasi sebagai health consciousness. Segmen ini bercirikan seperti berikut: mementingkan kesehatan dengan mengkonsumsi makanan dan minuman yang rendah kalori, serta menjaga kesehatan dengan melakukan diet.

Faktor 6 terdiri dari item-item yang disebut dengan adventurism life style. Karakteristik konsumen pada segmen ini adalah menyukai tempat-tempat ataupun hal-hal yang baru, senang melakukan traveling mengunjungi daerah baru.

Faktor 7 terdiri dari item-item yang teridentifikasi sebagai segmen community consciousness. Konsumen pada segmen ini memiliki karakteristik seperti berikut: menjadi anggota didalam suatu organisasi, memiliki kepedulian sosial yang tinggi, merasa menjadi bagian didalam suatu komunitas masyarakat, selalu berpartisipasi dalam kegiatan masyarakat.

Faktor 8 terdiri dari item-item yang teridentifikasi sebagai caring life style. Pada segmen ini konsumen didefinisi sebagai individu yang sangat memperhatikan segala sesuatu yang bernilai dan dianggap penting untuk dirinya sendiri.

Faktor 9 terdiri dari item-item yang teridentifikasi sebagai casualness. Konsumen pada segmen ini adalah individu yang tidak menyukai sesuatu yang formal dan tidak perduli akan sesuatu hal. Hal ini dapat dijelaskan dengan karakteristik seperti: menyukai pembayaran secara tunai atau cash, tidak perduli dengan kebersihan rumah/kamarnya.

Faktor 10 terdiri dari item-item yang teridentifikasi sebagai practicality. Karaktetristik dari segmen ini adalah konsumen yang menyukai hal-hal yang praktis atau instan dan menganggap memiliki kartu kredit merupakan hal yang baik.

Faktor 11 terdiri dari item-item yang teridentifikasi sebagai community consciousness. Konsumen pada segmen ini dapat dijelaskan dengan karateristik seperti berikut: Konsumen yang mencari nilai terbaik untuk setiap 
biaya yang dikeluarkan, selalu melihat harga yang tertera dalam suatu produk, melakukan tawar-menawar dalam melakukan pembelian, dan konsumen yang beranggapan dapat menghemat uang jika membuat pakaian sendiri.

Faktor 12 terdiri dari item-item yang teridentifikasi sebagai gaya hidup craftmanship. Karakteristik konsumen pada segmen ini adalah konsumen yang ingin menjadi individu yang ahli dalam keterampilan yang dimilikinya, sering menggunakan keterampilan yang dimiliki, dan menciptakan sesuatu yang bisa dimanfaatkan dari keterampilannya.

Faktor 13 terdiri dari item-item yang teridentifikasi sebagai extroversion. Segmen ini menjelaskan karakteristik dari suatu individu yang lebih mementingkan hal-hal yang lahiriah contohnya seperti lebih menyukai datang kesebuah pesta dari pada berdiam diri dirumah ataupun sebaliknya.

Selanjutnya faktor-faktor yang terbentuk diuji reliabilitasnya untuk menjamin kekonsistenan dari indikan-indikan yang digunakan untuk membentuk faktornya (Lihat Tabel 3). Hasilnya mengindikasi bahwa masing-masing item mempunyai konsistensi internal yang tinggi untuk menjelaskan faktornya (Cronbach's alpha >0,40).

Selanjutnya adalah pembahasan hasil pengujian tentang hubungan antara gaya hidup yang terbentuk dan niat pembelian terhadap merek asing dan lokal. Studi ini menggunakan pengujian statistik logistic regression dengan menggunakan SPSS 11.5 for Windows dengan metode forward stepwise. Namun sebelum membahasnya terlebih dahulu dikemukakan hasil pengujian model fit yang diperoleh.
-2Log Likelihood (-2LogL) test. Hasil pengujiannya mengindikasi bahwa step awal untuk melakukan pengujian regresi secara forward stepwise menghasilkan nilai -2LogL sebesar 346,510 yaitu suatu nilai jika semua variabel independen tidak dimasukan dalam model. Selanjutnya Tabel 4 juga menginformasikan tahapan-tahapan cara memasukan variabel independen ke dalam pengujian logistic regrresion melalui score dan signifikansi yang diperoleh. Tahapan-tahapan yang dimaksud adalah step 1, variabe leadership (score= 12,858 ; sig $=0,000$ ), step 2 variabel caring $($ score $=10,957 ; \operatorname{sig}=0,001)$, step 3 variabel fashion consciousness (score $=10,423$; sig $=$ 0,001 ), step 4 variabel extroversion (score= 9,355; sig= 0,002), step 5 variabel advedturism (score $=3,146 ;$ sig $=0,053$ ), step 6 variabel health consciousness ( score $=3,423$; sig= 0,076 ).

Langkah berikutnya variabel yang dimasukan adalah variabel yang dapat menambah nilai maksimum antar kelompok. Tabel 5 mengindikasi bahwa variabel yang dapat menambah nilai maksimum antar kelompok yaitu: leadership, caring, fashion conscioucness, health consciousness, extroversion. Sedangkan variabel advedturism tidak dimasukan kedalam model karena tidak dapat menambah nilai maksimum antar kelompok variabel.

Dari tabel 4 dan Tabel 5 dapat dijelaskan bahwa setelah dimasukan 5 variabel bebas secara signifikan menambah nilai model fit. Hal ini berarti penambahan variabel leadership, caring, fashion conscioucness, health consciousness, dan extroversion ke dalam model memperbaiki model fit.

Tabel 3: Hasil Uji Reliabilitas

\begin{tabular}{lcc}
\hline Variabel & Jumlah item & Cronbach's Alpha \\
\hline Family Orientation & 6 & 0,7396 \\
Fashion Consciousness & 8 & 0,8197 \\
Health Consciousness & 3 & 0,7596 \\
Leadership & 5 & 0,7580 \\
Caring & 3 & 0,7797 \\
Casualness & 3 & 0,7004 \\
Practicality & 3 & 0,6733 \\
Craftsmanship & 3 & 0,6170 \\
Community Consciousness & 4 & 0,6483 \\
Cost Consciousness & 3 & 0,7385 \\
Extroversion & 3 & 0,6433 \\
Adventurism & 2 & 0,8976 \\
Interest in Sport & 3 & 0,8293 \\
\hline
\end{tabular}


Tabel 4: Hasil -2Log Likehood (-2LogL)

\begin{tabular}{|c|c|c|c|c|}
\hline & & & Value & \\
\hline $\begin{array}{l}-2 \mathrm{Lo} \\
\text { Varic }\end{array}$ & $\begin{array}{l}\text { ikelihood } \\
\text { l not in th }\end{array}$ & & 346,510 & \\
\hline & & & Score & Sig \\
\hline Step & Variabel & Family Orientation & ,228 & 633 \\
\hline 0 & & Fashion Consciousness & 10,423 & ,001 \\
\hline & & Health Consciousness & 3,146 & 076 \\
\hline & & Leadership & 12,858 & 000 \\
\hline & & Caring & 10,957 & 001 \\
\hline & & Casualness & 1,068 & ,302 \\
\hline & & Practicality & ,762 & ,383 \\
\hline & & Craftmanship & 033 & ,856 \\
\hline & & Cost Consciousness &, 000 & ,990 \\
\hline & & Community Consciousness &, 015 & ,902 \\
\hline & & Extroversion & 9,355 & ,002 \\
\hline & & Advedturism & 3,754 & 053 \\
\hline & & Interest in Sport & 1,653 & ,199 \\
\hline & Overall s & & 38,541 & 000 \\
\hline
\end{tabular}

Tabel 5: Iretation History

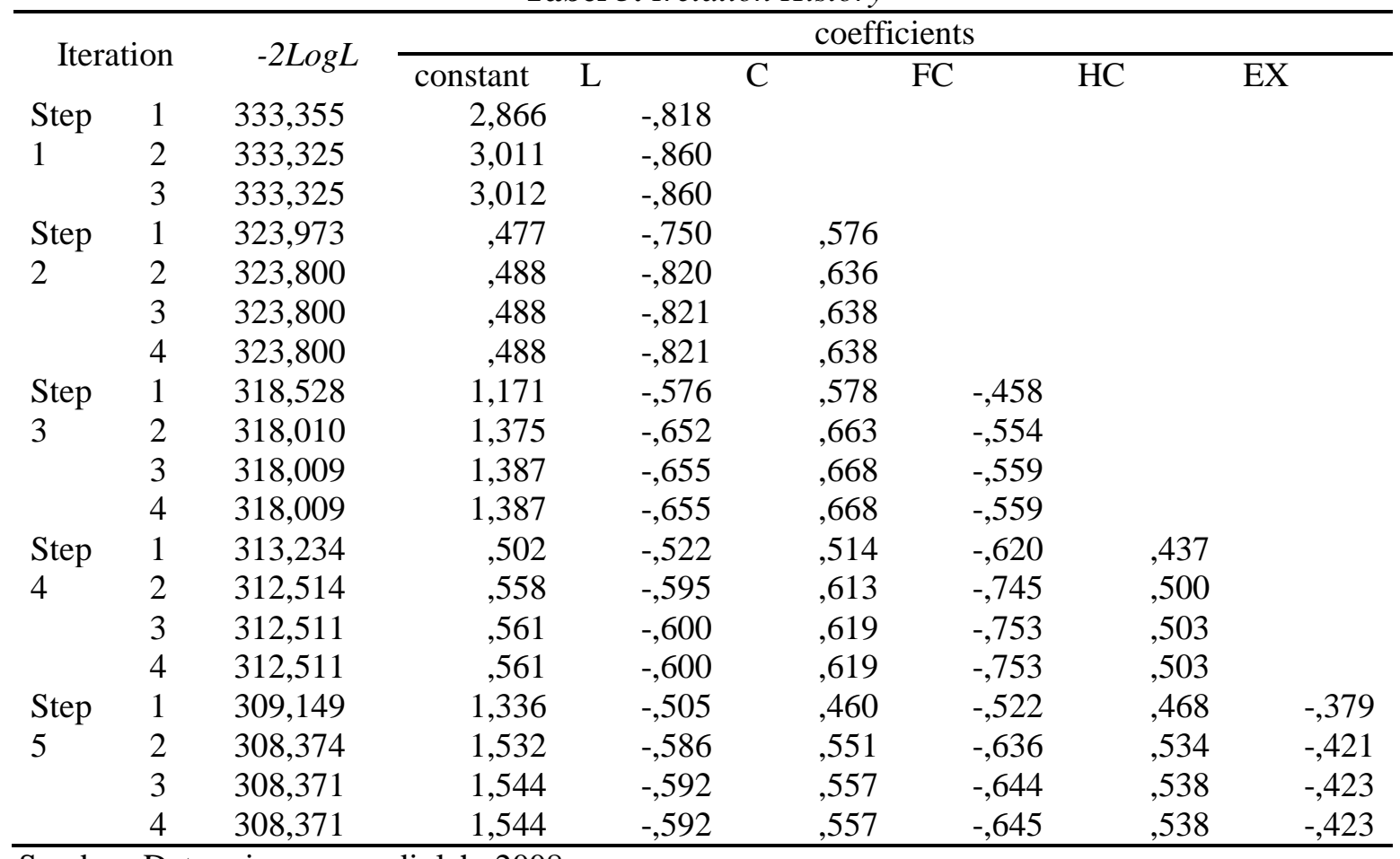

Sumber: Data primer yang diolah, 2008

Cox \& Snell R Square dan Nagelkerke $R$ Square. Cox dan Snell's $R^{2}$ merupakan ukuran yang serupa dengan ukuran $\mathrm{R}^{2}$ pada multiple regression yang didasarkan pada teknik estimasi likelihood dengan nilai maksimum kurang dari 1.0 sehingga sulit diinterpretasikan. Sedangkan Nagelkerke $R$ Square merupakan modifikasi dari koefisien Cox dan Snell's untuk memastikan nilainya bervariasi dari 0.0 hingga 1.0. Hal ini dilakukan dengan cara membagi nilai Cox dan Snell's $R^{2}$ dengan nilai maksimumnya. 
Tabel 6: Model Summary

\begin{tabular}{cccc}
\hline Step & -2 Log likelihood & Cox \& Snell R Square & Nagelkerke R Square \\
\hline 1 & 333,325 &, 051 &, 069 \\
2 & 323,800 &, 087 &, 116 \\
3 & 318,009 &, 108 &, 144 \\
4 & 312,511 &, 127 &, 170 \\
5 & 308,371 &, 141 &, 189 \\
\hline
\end{tabular}

Tabel 7: Hosmer and Lemeshow Goodness of Fit

\begin{tabular}{lccc}
\hline Step & Chi-square & Df & Sig. \\
\hline 1 & 9,053 & 7 &, 249 \\
2 & 7,628 & 8 &, 471 \\
3 & 13,296 & 8 &, 102 \\
4 & 12,277 & 8 &, 139 \\
5 & 9,796 & 8 &, 280 \\
\hline
\end{tabular}

Tabel 8: Tabel Klasifikasi

\begin{tabular}{|c|c|c|c|c|c|}
\hline & \multirow{3}{*}{ Observed } & & \multicolumn{3}{|c|}{ Predicted } \\
\hline & & & \multicolumn{2}{|c|}{ NIAT } & \multirow{2}{*}{$\begin{array}{c}\text { Percentage } \\
\text { Correct }\end{array}$} \\
\hline & & & 0 & 1 & \\
\hline \multirow[t]{3}{*}{ Step 1} & NIAT & 0 & 70 & 57 & 55,1 \\
\hline & & 1 & 54 & 69 & 56,1 \\
\hline & Overall Percentage & & & & 55,6 \\
\hline \multirow[t]{3}{*}{ Step 2} & NIAT & 0 & 76 & 51 & 59,8 \\
\hline & & 1 & 47 & 76 & 61,8 \\
\hline & Overall Percentage & & & & 60,8 \\
\hline \multirow[t]{3}{*}{ Step 3} & NIAT & 0 & 80 & 47 & 63,0 \\
\hline & & 1 & 44 & 79 & 64,2 \\
\hline & Overall Percentage & & & & 63,6 \\
\hline \multirow[t]{3}{*}{ Step 4} & NIAT & 0 & 76 & 51 & 59,8 \\
\hline & & 1 & 45 & 78 & 63,4 \\
\hline & Overall Percentage & & & & 61,6 \\
\hline \multirow[t]{3}{*}{ Step 5} & NIAT & 0 & 77 & 50 & 60,6 \\
\hline & & 1 & 44 & 79 & 64,2 \\
\hline & Overall Percentage & & & & 62,4 \\
\hline
\end{tabular}

Ket: kode $0=$ niat pembelian KFC, kode 1= niat pembelian Ayam Bakar Wong Solo

Hasil pengujian menjelaskan bahwa nilai Cox Snell's $R$ Square sebesar 0,141dan nilai Nagelkerke $R$ Square sebesar 0,189. Hal ini berarti variabilitas variabel dependen yang dapat dijelaskan oleh variabel independen sebesar 18,9\%, sedangkan yang lainnya dijelaskan oleh variabel lain.

Hosmer and Lemeshow Goodness of Fit. Pengujian ini dimaksudkan untuk menguji hipotesis nol bahwa data empiris sesuai dengan model. Hasilnya mengindikasi bahwa semua model adalah fit, karena menolak H0 yang mengatakan model tidak fit sehingga dapat menjelaskan fenomena yang diuji (Tabel 7).

Tabel klasifikasi 2 × 2 (Tabel 8). Tabel ini menjelaskan bahwa responden yang memiliki niat pembelian pada KFC ada 127 responden, sedangkan hasil observasi hanya 77 responden jadi ketepatan klasifikasinya sebesar 60,6\%. Selanjutnya responden yang memiliki niat pembelian pada Ayam Bakar Wong solo ada 123 responden, sedangkan hasil observasi hanya 79 responden jadi ketepatan klasifikasinya adalah $64,2 \%$. Sehingga secara keseluruhan ketepatan kalsifikasi adalah 62,4\% (Lihat Tabel 8).

Berikutnya adalah pembahasan terhapap hasil pengujian hipotesis. Pengujian hipotesis dilakukan dengan menganalisis tingkat signifikansi pengaruh variable independen terhadap variable dependen dalam model. Pengujian ini didasarkan pada nilai estimasi maksimum likelihood parameter dari model pada tampilan output variable in the equation. Logistic regression dapat diformulasikan sebagai berikut: 


$$
\begin{gathered}
\log i t_{i}=\ln \left(\frac{\text { prob }_{\text {event }}}{1-\text { prob }_{\text {event }}}\right)=b_{0}+b_{1} X_{1}+\ldots+b_{n} X_{n} \\
\text { odds }_{i}=\ln \left(\frac{\text { prou }_{\text {event }}}{1-\text { prob }_{\text {event }}}\right)=e^{b_{0}+b_{1} X_{1}+\ldots+b_{n} X_{n}}
\end{gathered}
$$

Pengaruh fashion consciousness pada niat pembelian. Hasil pengujian menunjukkan bahwa fashion consciousness berpengaruh negatif terhadap niat pembelian $(\mathrm{B}=-0,645 ; \mathrm{sig}$ $=0,014)$. Hal ini menjelaskan bahwa semakin tinggi gaya hidup fashion consciousness konsumen, maka semakin tinggi probabilitas konsumen memiliki niat pembelian pada KFC. Fenomena ini terjadi kemungkinan dikarenakan oleh konsumennya yang fashionable, mengikuti trend atau mode terbaru, sangat mempertimbangkan dalam melakukan pembelian terhadap suatu produk ataupun merek, dan menggunakan informasi dalam melakukan pembelian, sehingga berkecenderungan untuk memilih merek luar negeri.

Pengaruh health consciousness pada niat pembelian. Hasil pengujian menunjukkan bahwa health consciousness berpengaruh positif terhadap niat pembelian $(\mathrm{B}=0,538$; sig.= 0,015). Fenomena yang dideskripsikan adalah semakin tinggi gaya hidup health consciousness pada konsumen semakin tinggi probabilitas niat pembelian konsumen pada Ayam Bakar Wong Solo. Hal ini dapat terjadi karena konsumen dengan gaya hidup seperti ini mementingkan kesehatan dan melakukan diet untuk menjaga kesehatan. Sehingga konsumen tersebut berkecenderungan untuk lebih berniat untuk membeli Ayam Bakar Wong Solo yang dikonotasikan lebih sehat daripada KFC yang termasuk jenis produk makanan fast food yang dikonotasikan sebagai produk yang mengandung banyak lemak tak jenuh.

Pengaruh leadership pada niat pembelian. Hasil pengujian menunjukan bahwa leadership berpengaruh negatif terhadap niat pembelian $(B=-0,592$; sig $=0,026)$. Hal ini menjelaskan bahwa semakin tinggi gaya hidup leadership konsumen semakin tinggi probabilitas niat pembelian pada KFC. Alasan yang mendasari niat pembelian pada KFC adalah karateristik konsumen dengan gaya hidup seperti ini selalu merasa dirinya sebagai pemimpin yang memiliki gengsi tinggi ter-

\begin{tabular}{|c|c|c|c|c|c|c|c|c|c|}
\hline \multicolumn{2}{|r|}{ Model } & \multicolumn{6}{|c|}{ Keterangan } & \multicolumn{2}{|c|}{$\begin{array}{c}95.0 \% \text { C.I for } \operatorname{Exp} \\
(\beta)\end{array}$} \\
\hline & & $\mathrm{B}$ & S.E & Wald & $\mathrm{df}$ & Sig. & $\operatorname{Exp}(\beta)$ & Lower & Upper \\
\hline Step & $\mathrm{L}$ &,- 860 & ,246 & 12,256 & 1 &, 000 &, 423 & ,261 & ,685 \\
\hline $1(\mathrm{a})$ & Constant & 3,012 &, 877 & 11,782 & 1 & ,001 & 20,326 & & \\
\hline Step & $\mathrm{L}$ &,- 821 & ,249 & 10,881 & 1 & ,001 &, 440 &, 270 &, 717 \\
\hline \multirow[t]{2}{*}{ 2(b) } & $\mathrm{C}$ & ,638 & ,212 & 9,032 & 1 & ,003 & 1,892 & 1,248 & 2,867 \\
\hline & Constant &, 488 & 1,189 &, 168 & 1 & 682 & 1,629 & & \\
\hline Step & $\mathrm{FC}$ &,- 559 & ,238 & 5,539 & 1 & ,019 &, 572 & ,359 & 911 \\
\hline \multirow[t]{3}{*}{$3(\mathrm{c})$} & $\mathrm{L}$ &,- 655 & ,261 & 6,328 & 1 & ,012 &, 519 & ,312 &, 865 \\
\hline & $\mathrm{C}$ & ,668 &, 216 & 9,540 & 1 &, 002 & 1,949 & 1,276 & 2,978 \\
\hline & Constant & 1,387 & 1,270 & 1,192 & 1 & ,275 & 4,002 & & \\
\hline Step & $\mathrm{FC}$ &,- 753 &, 255 & 8,701 & 1 & ,003 &, 471 & ,286 & ,777 \\
\hline \multirow[t]{4}{*}{$4(d)$} & $\mathrm{HC}$ &, 503 & ,219 & 5,291 & 1 &, 021 & 1,654 & 1,077 & 2,540 \\
\hline & $\mathrm{L}$ &,- 600 & ,263 & 5,193 & 1 &, 023 &, 549 & ,328 & ,920 \\
\hline & $\mathrm{C}$ & ,619 &, 220 & 7,894 & 1 &, 005 & 1,857 & 1,206 & 2,861 \\
\hline & Constant &, 561 & 1,324 &, 179 & 1 & 672 & 1,752 & & \\
\hline Step & $\mathrm{FC}$ &,- 645 & ,261 & 6,089 & 1 &, $014 *$ &, 525 & ,315 & ,876 \\
\hline \multirow[t]{5}{*}{$5(d)$} & $\mathrm{HC}$ &, 538 & ,221 & 5,905 & 1 &, $015^{*}$ & 1,712 & 1,110 & 2,641 \\
\hline & $\mathrm{L}$ &,- 592 & ,265 & 4,966 & 1 &, $026 *$ &, 553 & ,329 & ,931 \\
\hline & $\mathrm{C}$ &, 557 & ,222 & 6,285 & 1 &, $012 *$ & 1,746 & 1,129 & 2,699 \\
\hline & $\mathrm{EX}$ &,- 423 & ,211 & 4,033 & 1 &, $045^{*}$ &, 655 & ,433 & ,990 \\
\hline & Constant & 1,544 & 1,433 & 1,161 & 1 &, 281 & 4,685 & & \\
\hline
\end{tabular}
hadap produk asing.

Tabel 9: Hasil Uji Logistic regression

Ket: -kode 0= niat pembelian KFC, kode 1= niat pembelian Ayam Bakar Wong Solo

-*signifikan pada alpha 0,05 
Pengaruh caring terhadap niat pembelian. Hasil pengujian menunjukkan bahwa caring berpengaruh positif terhadap niat pembelian $(\mathrm{B}=0,557$; sig $=0,012)$. Hal ini menjelaskan bahwa semakin tinggi caring gaya hidup konsumen semakin tinggi probabilitas niat pembelian pada Ayam Bakar Wong Solo. Hal ini dikarenakan konsumen dengan gaya hidup ini sangat memperhatikan sesuatu yang bernilai dan berharga didalam melakukan pembelian atau mengkonsumsi suatu produk untuk dirinya. Sehingga konsumen dengan gaya hidup seperti ini lebih memiliki niat pembelian pada Ayam Bakar Wong Solo daripada KFC.

Pengaruh antara extroversion terhadap niat pembelian. Hasil pengujian menunjukan bahwa extroversion berpengaruh negatif terhadap niat pembelian $(\mathrm{B}=-0,432$; sig $=$ $0,045)$. Fenomena yang dideskripsikan adalah semakin tinggi gaya hidup extroversion pada konsumen semakin tinggi probabilitas niat pembelian pada KFC. Hal ini dikarenakan sebagaian besar konsumen ini tergolong berusia muda yang hanya mementingkan hal-hal lahiriah untuk dirinya sendiri dan kurang memperhatikan sesuatu hal yang berharga lainnya. Dengan demikian, konsumen dengan gaya hidup seperti ini berkecenderungan memiliki niat pembelian yang tinggi pada KFC sebagai produk asing.

\section{PENUTUP}

Hasil pengujian yang diperoleh mengindikasi beberapa variabel yang berpengaruh pada niat pembelian. Pertama, fashion consciousness berpengaruh negatif pada niat pembelian. Hal ini menjelaskan bahwa semakin tinggi fashion consciousness, semakin tinggi probabilitasnya untuk berniat membeli KFC. Kedua, health consciousness berpengaruh yang positif pada niat pembelian. Hal ini menjelaskan bahwa semakin tinggi health conciousness konsumen, semakin tinggi probabilitas konsumen untuk berniat membeli Ayam Bakar Wong Solo. Ketiga, leadership berpengaruh negatif pada niat pembelian. Hal ini berarti bahwa semakin tinggi leadership konsumen, semakin tinggi probabilitasnya untuk membeli KFC. Keempat, caring berpengaruh positif pada niat pembelian. Hal ini menjelaskan bahwa semakin tinggi caring, semakin tinggi probabilitas kon- sumen untuk berniat membeli Ayam Bakar Wong Solo. Kelima, extroversion berpengaruh negatif pada niat pembelian. Hal ini mengindikasi bahwa semakin tinggi extroversion konsumen, semakin tinggi probabilitasnya untuk berniat membeli KFC.

Saran secara praktis, studi ini diharapkan dapat memberikan pemahaman kepada praktisi terhadap upaya-upaya untuk memahami dimensi gaya hidup dalam upaya untuk meningkatkan kinerja pemasarannya melalui niat pembelian konsumen yang diharapkan.

Saran secara teoritis, studi ini diharapkan dapat digunakan sebagai acuan dalam studi-studi keperilakuan konsumen khususnya yang mengungkap isu segmentasi gaya hidup. Hal ini dikarenakan studi ini mengungkap fenomena gaya hidup dengan menggunakan setting dan bertumpu pada prosedur pengujian yang berbeda dari studi-studi terdahulu sehingga diharapkan menghasilkan model keperilakukan yang mempunyai keunikan yang berbeda. Dengan demikian, studi ini dapat digunakan sebagai referensi yang dapat dikembangkan dan diuji lagi pada konteks yang lebih luas.

Model yang dikembangkan bertumpu pada metode riset yang terbatas ruang lingkupnya yaitu niat pembelian KFC dan Ayam Bakar Wong Solo yang berlatangbelakang pengujian Surakarta. Hal ini berdampak pada keterbatasan model untuk diaplikasi pada setting dan konteks yang berbeda. Keterbatasan ini mengisyaratkan perlunya mencermati segala perbedaan yang terjadi, jika ingin menggeneralisasi model penelitian ini pada konteks yang berbeda, sehingga tidak mengalami pembiasan dalam mengintepretasi konsep-konsepnya.

\section{REFERENSI}

Assael, H. 1998. Consumer Behavior and marketing action. Cincinnati. Ohio: Shouth-western College.

Atchariyachanvanich and Okada. 2007. How Consumer life style Affect Purchasing Behavior: Evidence from Internet Shopping in Japan. Journal of Entrepreneurship Research. 2(2). 63-78.

Ghozali, I. 2004. Aplikasi Analisis Multivariate dengan Program SPSS. Semarang: 
Badan Penerbit Universitas Diponegoro.

Hair, JF., E.A. Rolph, L.T. Reynolds and C.B. William. 1998. Multivariate Data Analysis. New Jersey: Pretice Hall International, Inc.

Kaynak, K. and A. Kara, 2001. An examination of the relationship among consumer gaya hidups, ethnocentrism, knowledge structures, attitudes and behavioural tendencies: a comparative study in two CIS states. International Journal of Advertising. 20. 455-482.

Kavak, V. and Gumusluoglu. 2006. Segmenting food markets; the role of ethnocentrism and life style in understanding purchasing intentions. International Journal of Market Research. 49(1).

Kotler, P. 1994. Manajemen Pemasaran: Analisis, Perencanaan, Implementasi, dan Pengendalian. Jakarta: Erlangga.

2004. Marketing Insight From A to Z. Jakarta: Penerbit Erlangga.

Mitchell, A. 1983. The nine American Life Styles. New York: Warner.

Naylor, G. and S. B. Kleiser. 2002. Exploring the differences in perceptions of satisfaction across life style segments.
Journal of Vacation Marketing. 8(4). ABI/INFORM Global pg. 343

Sekaran, U. 2000. Research Method of Business Hermitage Publishing Service.

Shieh, K.F. and M.S. Cheng. 2007. An empirical study of experiental value and life style, and their effects on satisfaction in adolescents: An example using online gaming. San Diego: Libra Publishers, Inc.

Sproles, G. and E. Kendall. 1986. A Methodology for Profiling Consumer's Decision Making Style, The Journal of Consumer Affairs. 20(2). 267 - 279.

Suara Merdeka. 2007.UMK Semarang Tetap, $20 \quad$ November 2007. http://www.google.com/UMK_Surakart a/Suara Merdeka (online) Diakses 10 November 2008.

Versantvoort, G.A. and V.D. Laan. 1997. Analysing labour supply in a life-style perspective, Erasmus Centre for Labour Market Analysis (ECLA) and Tinbergen Institute; Erasmus University Rotterdam. Netherlands.

Wells, W.D. 1975. Psychographics: A critical review. Journal of marketing research. 12. 196-213. 